\title{
Hepatoprotective and Histologic effects of Lactic Acid Bacteria on Carbon Tetrachloride - Induced Liver Injury in Albino Rats (Rattus Albus)
}

\author{
Hinay Alfredo Jr*, Bandoy Anna-Lee, Sagsagat, Hannah Andrea, Allen Czanille June, Ratilla Aina and Roble \\ Deborah Esther
}

Faculty of Medical Laboratory Science, University of the Immaculate Conception, Davao City, Philippines

Submission: November 26, 2018; Published: January 18, 2019

*Corresponding author: Alfredo A Hinay, Division of Virology, Faculty of Medical Laboratory Science, University of the Immaculate Conception, Davao City, Philippines

\begin{abstract}
Liver disease has long been a problem to the public health. There are different etiologic agents to this problem such as hepatotoxins and alcoholism, which contribute to liver damage or necrosis, biologic factors such as bacteria, parasites and viruses, metabolic diseases, and even drug exposure to paracetamol or carbon tetrachloride etc. Hence, a growing need to provide an effective and safe drug has become a trend because current modern available drugs have side effects and bring about inherent toxicities. Two locally known commercially fermented products were used as the source of lactic acid bacteria. These were the coconut toddy (tuba) and Visayan fermented fish (guinamos). Three distinct colonies were isolated - two from the guinamos coded as GUI - 01 and GUI - 02, and one from the tuba coded as TUB - 01. However, only the colony isolated from tuba was subcultured in MRS broth as it was stipulated in the delimitations of the study to use only bacteria of genus Lactobacillus. The colony isolated from the tuba was characterized as Gram positive, catalase negative, oxidase negative, non - spore forming bacilli in single and clusters. The MRS broths incubated for 72 hours at $37^{\circ} \mathrm{C}$ were pelleted by centrifugation and re-suspended in $0.1 \mathrm{M}$ Phosphate Buffer Solution (pH 7.4).

The isolates were investigated for their hepatoprotective and histologic effects on carbon tetrachloride - induced liver injury in Albino rats (R. albus), along with Silymarin as the positive control. For four days, the albino rat test groups were administered with a single dose lactic acid bacteria suspension, while positive control group was induced with a single dose silymarin. Results showed only slight elevations of serum ALT and AST on group induced with LAB, as compared to the levels of serum ALT and AST on group induced with silymarin. Using One - way Analysis of Variance, it was suggested that lactic acid bacteria has comparable effects to the hepatoprotective effects of Silymarin against carbon tetrachloride. This result was supplemented by the histopathologic exams of rat liver sections showing normal histology.
\end{abstract}

Keywords: Lactic acid bacteria; Hepatoprotective effects; Visayan fermented fish; Coconut toddy

\section{Introduction}

The progression of liver disease begins with hepatitis followed by cirrhosis and leads to liver failure or hepatoma. But the precise pathological mechanisms of chronic disease progression are still unclear [1]. Moreover, recent data showed that different agents can be contributors to the damage such as biological factors (examples are Fasiola hepatica, Hepatitis A virus and Helicobacter spp.) and autoimmune diseases (immune hepatitis and primary biliary cirrhosis), as well as by the action of different chemicals, such as some drugs and their metabolites (high doses of paracetamol and antitubercular drugs), toxic compounds (carbon tetrachloride, thioacetamide, dimethylnitrosamine, D-galactosamine/ Lipopolysaccharide, and tert-butyl hydroperoxide), and certainly, excessive consumption of alcohol. This makes chronic liver disease and cirrhosis ranked $5^{\text {th }}$ as the leading causes of death after heart disease, stroke, chest disease, and cancer [2].

However, even with the advances in modern medicine, there are no completely effective drugs that can initiate hepatic function, provide complete protection to the organ, or aid in the regeneration of hepatic cells. They have potential adverse effects especially when taken sub - chronically or chronically [3]. Moreover, journals quoted that synthetic drugs have little contribution for the improvement in hepatic disease [4]. Hence, probiotics have been adapted to treat liver disorders, with the aim that these agents must be more effective and less toxic. Lactic acid bacteria are important intestinal microflora and are traditionally used in the production of fermented foods and beverages such as in cheese, wine coconut toddy, and fermented fish [5]. Moreover, giving the importance of intestinal flora in liver disease, lactic acid bacteria (which is a probiotic) can also provide an effective dietary approach to improve hepatic encephalopathy and to decrease the risk of liver cancer.

Though many pharmacological benefits of lactic acid bacteria have postulated such as maintaining intestinal microbial system and improving immune function, still, little work has been done to 
explore the hepatoprotective effects of lactic acid bacteria to date [4]. This study aimed to know the hepatoprotective and histologic effects of lactic acid bacteria isolated from commercially available fermented food products. This will also help pharmaceutical industries to provide a solution for the increasing mortality rates of liver disease by providing them ideas so that they can generate new and more effective drug to protect the liver from further damage.

\section{Material and Methods}

\section{Sample Collection}

The study engaged purposive sampling method were the samples taken only from Bankerohan Public Market, Davao City. The guinamos utilized in this study had dilis as the type of fish, and was 30 days old. Having a pale gray to white color, this indicated that fermentation is present [6]. On the other hand, the coconut toddy used was a Bahal (60 days old), a type of coconut toddy wherein the fermentation process lasted 2-3 months. The coconut toddy contained a color dye which provided its reddish-brown or brownish-pink color

\section{Lactic Acid Bacteria (LAB) Suspension}

To prepare 2.5 X 106 bacterial suspensions, $4 \mathrm{~mL}$ of LAB pellet was suspended with $16 \mathrm{~mL} 0.1 \mathrm{M}$ Phosphate buffer solution $\mathrm{pH}$ 7.4). Neubauer counting chamber was used to count the LAB. Both the five inner squares of the two counting chambers were counted. Each inner square contained 25 smaller squares. After counting the bacteria, the total number was solved using this formula:

$$
L A B \text { count }=\frac{\text { number of } L A B \text { cells counted } * \text { dilution factor }}{0.2 \mathrm{~mm}(\text { area }) \times 0.1(\text { depth })}
$$

\section{Protocol for Animal Experimentation}

Before starting the said experimentation, the researchers had complied all the requirements given by the Institutional Animal Care and use Committee (IACUC) and had received a certification. With the guidelines set by the IACUC, the albino rats ( $R$. albus) were placed in the animal house in the University of the Immaculate Conception.

\section{Albino Rats (Rattus albus)}

Twenty - five (25) male albino rats ( $R$. albus), weighing 150 to 250 grams (ages 8 to 12 weeks) were used in this study. They were subjected for a 7-day acclimatization and were individually housed in clean acrylic cages for 12 days at 20 to $26^{\circ} \mathrm{C}$ room temperature, and regular light cycles of $12 / 12$ hours light/dark for the entire experimentation. The albino rats (R. albus) were fed with commercial pelleted rat chow and water ad libitum. These animals received care according to the guidelines set by the Institutional Animal Care and Use Committee (IACUC).

The twenty - five (25) albino rats (R. albus) were divided into 5 groups coded with the following:

Group 1 (Negative Control) - No administration of Lactic Acid Bacteria, Silymarin and carbon tetrachloride.
Group 2 - albino rats orally administered with isolated Lactic acid bacteria strains (4 days, once a day)

Group 3 - albino rats orally administered with $0.85 \%$ Normal saline Solution (4 days, once a day), carbon tetrachloride induced (one hour after last administration of $0.85 \%$ normal saline solution)

Group 4 (Positive Control) - albino rats orally administered with Silymarin (4 days, once a day), carbon tetrachloride induced (one hour after last administration of Silymarin)

Group 5 (Test) - albino rats orally administered with isolated Lactic acid bacteria strains (4 days, once a day), carbon tetrachloride induced (one hour after last administration of lactic acid bacteria)

\section{Experimental Procedure}

Before the administration of the different agents, the albino rats ( $R$. albus) were subjected to acclimatization for 7 days. This allowed them to adjust to their new environment. The researchers used bent metal oral gavage measuring 3 inches long, with a gauge of 14 to aid in the administration of the said substances and a $1.0 \mathrm{ml}$ capacity tuberculin syringe without needle.

\section{Lactic Acid Bacteria Administration}

The albino rats ( $R$. albus) under group 2 and group 5 were orally given $1.0 \mathrm{ml}$ of $2.5 \times 106$ suspension of the isolated lactic acid bacteria ( $400 \mu \mathrm{l}$ per $16 \mathrm{ml}$ of $0.1 \mathrm{M}$ PBS buffer) for four days. The preparation of the lactic acid bacteria was based from the study of Han [4] with slight modifications.

\section{Silymarin Administration}

The albino rats ( $R$. albus) under group 2 (positive control) were orally given $1.0 \mathrm{ml}$ of the silymarin suspension (210 mg pure silymarin/16 $\mathrm{ml}$ of $0.85 \% \mathrm{NSS}$ ) for four days. This preparation was based from the study of Chu Chyn with slight modifications.

\section{$\mathbf{0 . 8 5} \%$ Normal Saline Solution}

The albino rats ( $R$. albus) under group 1 (negative control) and group 3 (control) were orally given $1 \mathrm{ml}$ of $0.85 \%$ Normal Saline Solution for four days.

\section{Carbon Tetrachloride Administration}

After an hour of the final administration of the different substances, 20 albino rats ( $R$. albus) were orally administered with carbon tetrachloride and olive oil $(2 \mathrm{ml} / \mathrm{kg} 50 \% \mathrm{v} / \mathrm{v})$. The dose administered depended on the weight of each albino rats (R. albus).

\section{Blood Collection}

Blood samples were taken via cardiac puncture after 18 hours. The samples collected were placed on red tap evacuated tubes and were allowed to clot at room temperature for 60 minutes. Centrifugation was done at 2000rpm for 10 minutes to allow serum separation. The serum samples were tested for the biochemical parameters - Aspartate aminotransferase and Alanine aminotransferase. The following procedures were done under the supervision and 
aid of the research adviser and the veterinarian to ensure proper performance of the methodologies.

\section{Necropsy}

After the blood collection, the albino rats ( $R$. albus) were sacrificed via cervical dislocation. After which, liver tissues were excised and were immediately stored in a sterile screw cap container having 10\% Neutral Buffered Formalin to start the fixation.

\section{Hepatoprotective Effects}

To measure the hepatoprotective effects of lactic acid bacteria, AST and ALT levels in serum samples of albino rats ( $R$. albus) were measured. The reference value for the albino rat ( $R$. albus) ALT is $18-45 \mathrm{U} / \mathrm{L}$, while the reference value for AST is $7-143 \mathrm{U} / \mathrm{L}$ [7].

\section{Histologic Effects}

The liver tissues were processed and embedded in paraffin after fixing with $10 \%$ Neutral Buffered Formalin. Sections were cut and were stained with hematoxylin and eosin. All of the tissues were viewed under light microscope by a pathologist to analyze any altered architecture of the liver tissues due to carbon tetrachloride, or if there were improvement in the liver architecture in those induced with lactic acid bacteria and silymarin [3].

\section{Results and Discussion}

\section{Identification of Lactic Acid Bacteria Isolated strains}

In isolating lactic acid bacteria, the two samples - the Visayan fermented fish and the coconut toddy, from which three colonies of distinct morphology were isolated. Subculture in duplicates using de Man Ragosa and Sharpe (MRS) agar were performed to ensure that only one kind of bacteria were isolated. Table 1 shows the data regarding the colonies isolated from tuba and guinamos sample. Upon proceeding to the presumptive identification of the bacterial isolates, the researchers performed gram staining, catalase test, and oxidase test. API $50 \mathrm{CH}$ was used for the species identification of the bacteria.

Table 1: Colony characteristic and screening for isolated lactic acid bacteria strains.

\begin{tabular}{|c|c|c|c|c|c|}
\hline \multicolumn{2}{|c|}{ Code } & Colony Characteristic & Gram-staining Reaction & Microscopic Morphology & API50 CH Identification \\
\hline $\begin{array}{c}\text { Tuba (Coconut } \\
\text { toddy) }\end{array}$ & TUB-01 & $\begin{array}{c}\text { small, creamy, opaque, } \\
\text { round, raised, dirty white to } \\
\text { smooth }\end{array}$ & $\begin{array}{c}\text { Gram - positive, non-spore } \\
\text { forming }\end{array}$ & $\begin{array}{c}\text { bacilli in single or cluster } \\
\text { arrangement }\end{array}$ & Lactobacillus plantarum \\
\hline $\begin{array}{c}\text { Guinamos } \\
\text { (Visayan fer- } \\
\text { mented fish) }\end{array}$ & GUI-01 & $\begin{array}{c}\text { Pinpoint, creamy, opaque, } \\
\text { round, raised, dirty white to } \\
\text { smooth }\end{array}$ & Gram - positive & $\begin{array}{c}\text { cocci in single or cluster } \\
\text { arrangement }\end{array}$ & $\begin{array}{c}\text { Leuconostoc mesenteroides } \\
\text { spp. Cremoris }\end{array}$ \\
\cline { 2 - 6 } & $\begin{array}{c}\text { Small, creamy, opaque, } \\
\text { round, raised, dirty white to } \\
\text { smooth }\end{array}$ & Gram - positive & $\begin{array}{c}\text { cocci in single or cluster } \\
\text { arrangement }\end{array}$ & Lactococcus lactis spp. Lactis \\
\hline
\end{tabular}

Gram staining revealed gram-positive, non-spore forming bacilli. No bubble formation was observed when the $3 \%$ hydrogen peroxide was added to the bacteria. Absence of purple coloration was also observed in the oxidase test. These results indicate that the organism was non - catalase and non - oxidase producing bacteria. The researches also confirmed the specific type of bacteria using the API. The bacteria isolated was Lactobacillus plantarum. However, even if three lactic acid bacteria were isolated from guinamos and tuba, only the LAB isolated from tuba were used due to the delimitations of the study to use only lactic acid bacteria with genus Lactobacilli.

According to Khemariya [8], Lactobacillus plantarum are gram - positive, non-spore forming lactobacilli that are usually isolated from fermented foods (such as fermented meat, fermented vegetables, and silage beverages), and are non - catalase producers. These characteristics strongly confirm that the isolated lactic acid bacteria were really Lactobacillus plantarum [8]. Moreover, the studies of Kadere, Kutima \& Wambugu $[9,10]$ also cited that Lactobacillus plantarum are present in coconut toddy.

\section{Hepatoprotective Effects}

The hepatoprotective effects of lactic acid bacteria strains by using the activities of serum hepatic markers, aspartate aminotransferase and alanine aminotransferase were measured. The overall results of the aspartate aminotransferase and alanine aminotransferase are presented in Table 2.

Table 2: Effect of Lactic Acid Bacteria and Silymarin on serum marker enzymes in CCl4 induced hepatic damage. ( $n=5$ in each group).

\begin{tabular}{|c|c|c|c|c|}
\hline GROUP & ALT (Reference) & Mean \pm SD & AST (Reference) & Mean \pm SD \\
\hline NEGATIVE CONTROL & $18-45 \mathrm{U} / \mathrm{L}$ & $56.4 \pm 16.55$ & $74-143 \mathrm{U} / \mathrm{L}$ & $134.85 \pm 2.33$ \\
\hline SILYMARIN+CCL4 & $18-45 \mathrm{U} / \mathrm{L}$ & $73 \pm 4.24$ & $74-143 \mathrm{U} / \mathrm{L}$ & $145.75 \pm 23.55$ \\
\hline NSS+CCL4 & $18-45 \mathrm{U} / \mathrm{L}$ & $167.82 \pm 204.97$ & $74-143 \mathrm{U} / \mathrm{L}$ & $193.4 \pm 42.13$ \\
\hline LAB + CCL4 & $18-45 \mathrm{U} / \mathrm{L}$ & $46.2 \pm 24.04$ & $74-143 \mathrm{U} / \mathrm{L}$ & $159.70 \pm 19.94$ \\
\hline LAB INDUCED & $18-45 \mathrm{U} / \mathrm{L}$ & $36.6 \pm 36.11$ & $74-143 \mathrm{U} / \mathrm{L}$ & $126.53 \pm 27.17$ \\
\hline
\end{tabular}


The group one (negative control) served as the researchers' basis for the initial levels of serum ALT and AST of the different rat groups. The test revealed $56.4 \pm 16.55$ as a result for serum ALT levels which indicated a slight elevation, with $134.85 \pm 2.33$ levels of AST which fell within normal range. This means that generally, the condition of the albino rats' ( $R$. albus) livers were in good shape. However, significant changes were seen in the results of albino rats induced with $0.85 \%$ NSS with carbon tetrachloride as compared to the negative control. Massive increase in both of the serum ALT and AST were shown which indicated that the albino rat livers were damaged by the carbon tetrachloride. As cited by Afzal [3], liver cells contain high concentrations of ALT and AST, that when hepatocytes are damaged, this causes the leaking - out of those liver specific enzymes into the serum, causing an increase in their normal levels. They also added that an increase in the two enzymes are good indicators of cellular damage and loss of functional integrity of the liver cell membrane [3].

An increase in the serum marker ALT was also observed on the group treated with silymarin and carbon tetrachloride. Slight elevation was also observed in the result of the group's serum AST levels. This may be due to the length of the application time of the silymarin. The treatment time was just too short for the silymarin to exhibit its hepatoprotective effect. The groups of Albino rats $(R$. albus) induced with lactic acid bacteria (group 2 and group 5) significantly altered the levels of serum ALT and AST. Comparing the results to the positive control which is the silymarin, there is only a slight elevation of the serum ALT in the group treated with lactic acid bacteria. This is also the same to the study of Zedan [11], wherein the capacity of Lactobacillus plantarum to protect the liver was elucidated by the low levels of AST and ALT in the serum of mice [11].

Testing the significant difference on the mean value of ALT and AST in rats treated with Lactic Acid Bacteria and control drug - Silymarin in CCL4 induced hepatic damage shows that the ALT $(p=0.261)$ and AST $(p=0.457)$ signifies that there is no significant difference between the mean value of ALT and AST in rats treated with Lactic Acid Bacteria and control drug - Silymarin in CCL4 induced hepatic damage. Statistically, the isolated lactic acid bacteria suspension has a comparable effect to the control drug Silymarin.

\section{Histologic Effects}
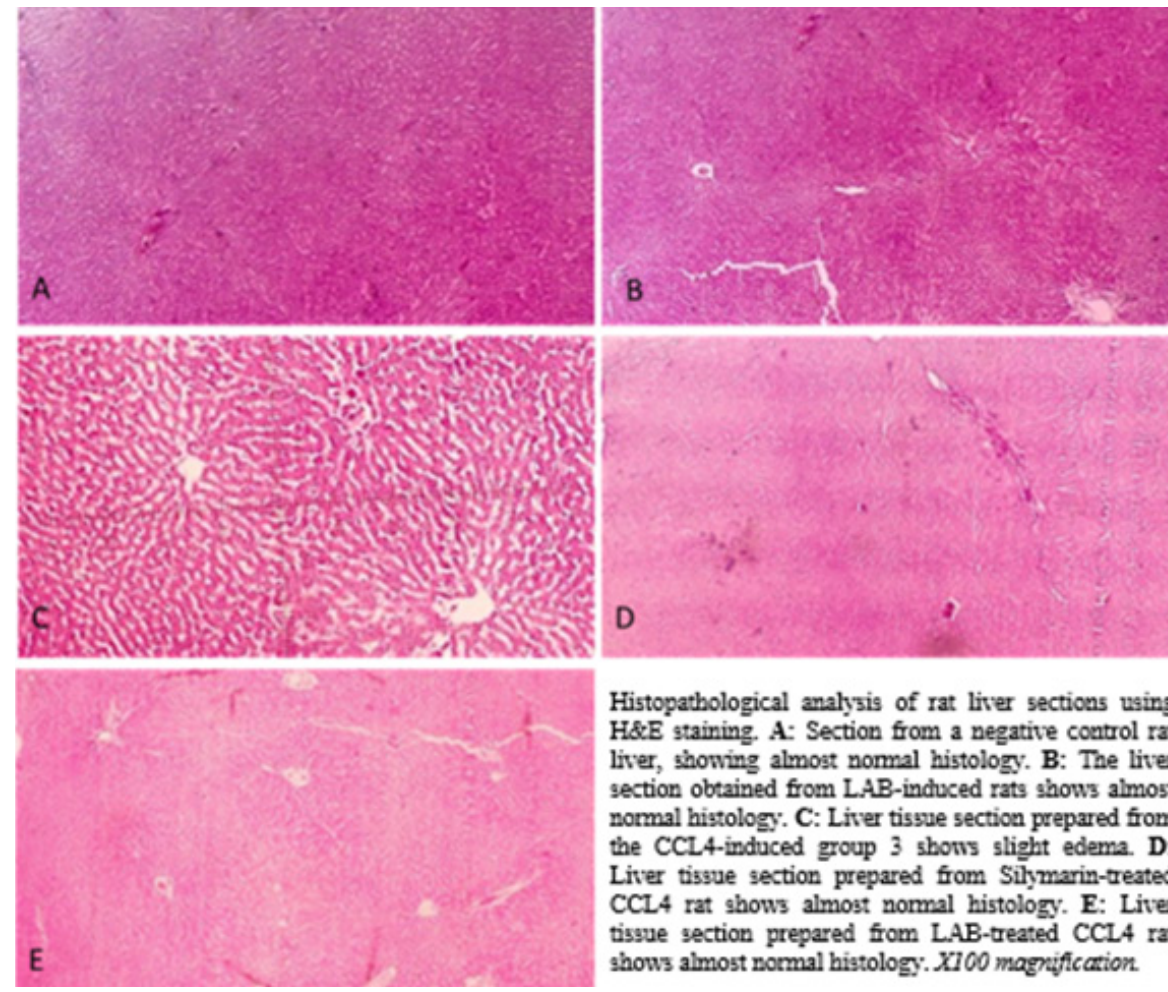

Histopathological analysis of rat liver sections using $H \& E$ staining. $A$ : Section from a negative control rat liver, showing almost nomal histology. B: The liver section obtained from L.AB-induced rats shows almost normal histology. C: Liver tissue section prepared from the CCL4-induced group 3 shows slight edema. D: Liver tissue section prepared from Silymarin-treated CCLA rat ghows almost normal histology. E: Liver tissue section prepared from L-AB-treated $\mathrm{CCL} 4$ rat shows almost normal histology. XI00 magriffication.

Figure 1 : Histological analysis of rat liver sections using H\&E staining.

Figure 1 shows the histopathological effects of the 5 different groups, absence of pathological abnormalities was seen in the groups 1, 2, 4, and 5, even if groups 2 and 4 were administrated with a single dose $2 \mathrm{ml} / \mathrm{kg}$ carbon tetrachloride and olive oil $(50 \%$ $\mathrm{v} / \mathrm{v}$ ). However, the administration of a single dose carbon tetrachloride and olive oil $(2 \mathrm{ml} / \mathrm{kg} 50 \% \mathrm{v} / \mathrm{v})$ in group 3 (albino rats induced with NSS) brought histological changes to their liver tissues.

According to the histological analysis, edema was observed in the liver tissues of the group 3 albino rats ( $R$. albus). In the study of Afzal [3], liver tissue treated with a single dose carbon tetrachlo- 
ride can cause several centrolobular necrosis, hepatocyte ballooning, and infiltration of inflammatory cells. However, it was evident that treatment with silymarin and lactic acid bacteria prevented any of those from happening.

Results signify that the isolated lactic acid bacteria were able to protect the albino rats' livers. This may be greatly attributed to the features cited by Chu-Chyn, that the lactic acid bacteria's ability to protect the hepatocytes begin when the LAB orally administered interacts with the digestive enzymes present in the digestive tract and follow their components after intestinal absorption to the liver where they exhibit their probiotic effects. This is also similar to the study of Levkut \& Herich [12], wherein they stipulated that lactic acid bacteria creates the barrier effect against pathogens and other hepatotoxic agents and produces regulatory factors such as short-chain fatty acids and bacteriocins [12]. Basing from the results of the AST and ALT levels, and the histological examination of the albino rats ( $R$. albus) liver tissue, the effectiveness of lactic acid bacteria was comparable to that of the positive control, which is silymarin.

\section{Conclusion}

The hepatoprotective effect of Lactobacillus plantarum 2 on carbon tetrachloride (CCL4) induced liver injury in albino rats is that it lowered the levels of serum Aspartate Aminotransferase and Alanine Aminotransferase, and showed a normal liver tissue when viewed microscopically. Further, there is no significant difference between the effects of the silymarin, a commercial hepatoprotective agent and the lactic acid bacteria in CCL4 induced hepatic damage on serum marker enzymes.

\section{References}

1. Chu-Chyn Ou Y (2011) Hepatoprotective effect of lactic acid bacteria in the attenuation of oxidative stress from tert-butyl Hydroperoxidase. Journal of Food and Drug Analysis, pp. 101-110.
2. Willams R (2006) Global challenges in liver disease. Hepatology pp. 521-526.

3. Afzal M, Khan R, Kazmi I, Anwar F (2013) Hepatoprotective potential of new steroid against carbon tetrachloride-induced hepatic injury. Molecular cellular biochemistry, pp. 275-281.

4. Han SY (2005) Hepatoprotective Effect of Lactic Acid Bacteria. Journal of Microbiology and Biotechnology pp. 887-888.

5. Ljungh, Wadstrom (2006) US National Library of Medicine National Institute.

6. Lee J, Kim J (2013) Development of cultural contex indicator of fermented food. International Journal of Bio-science and Biotechnology 5(4): 47.

7. Giknis M, Clifford C (2008) Clinical laboratory parameters for Crl:WI (Han). Charles River Laboratories.

8. Khemariya P, Singh S, Jaiswal N, Chauasia S (2016) Isolation and Identification of Lactobacillus plantarum from vegetable samples. Food Biotechnology 3(1): 49-62.

9. Kadere T, Kutima P (2012) Isolation and Identification of Lactic Acid Bacteria in Coconut toddy (Mnazi). Journal of Asian Scientific Research pp. 807-819.

10. Wabugu J (2015) Characterization of Lactic Acid Bacteria Isolated from Coconut Wine (MNAZI) for probiotic potential. Jomo Kenyatta University of Agriculture and Technology, Kenya.

11. Zedan Z (2011) Hepatoprotective effects of Lactobacillus plantarum against Salmonella typhimurium in mice. Journal of al-Nahrain university pp. 126-131.

12. Levkut M, Herich R (2002) Lactic acid bacteria, probiotics, and immune system. Vet Med Czech pp. $169-180$.

13. Jannu VB (2012) A review on hepatoprotective plants. International Journal of Drug Development and Research p. 1-8.

14. Vargas Mendoza MS (2014) Hepatoprotective effect of silymarin. 6(3): 144-149.

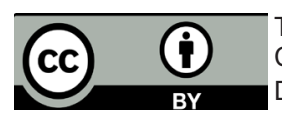

This work is licensed under Creative Commons Attribution 4.0 License DOI: 10.19080/JDVS.2019.09.555756 